\title{
VŠíMAVOSŤ A RIZIKOVÉ SPRÁVANIE U ADOLESCENTOV
}

\author{
Miriama Hudáková ${ }^{1}$, Katarína Havajová ${ }^{2}$ \\ 1Ústav aplikovanej psychológie FSVaZ UKF Nitra \\ ${ }^{2}$ Katedra psychologických vied FSVaZ UKF Nitra \\ mhudakova2@ukf.sk
}

\begin{abstract}
Abstrakt: Ciel'om štúdie bolo skúmat' vzt'ah medzi všímavost'ou a rizikovým správaním adolescentov. Pri skúmaní rizikového správania sme vychádzali z konceptu rozlišujúceho rizikové správanie spojené so zdravím a explorujúce správanie, ktoré s väčšou pravdepodobnost'ou prináša pozitívne dôsledky. Výskumnú vzorku tvorilo 166 študentov stredných škôl (51 chlapcov a 115 dievčat) vo veku od 15 do 20 rokov $\left(\mathrm{M}_{\mathrm{vek}}=17,2 ; \mathrm{SD}_{\mathrm{vek}}=1,49\right)$. Na meranie všímavosti sme použili Dotazník piatich aspektov všímavosti (Baer et al., 2006) a na meranie rizikového správania Škálu explorujúceho a rizikového správania (Skaar, 2009). Zistili sme, že rizikové správanie koreluje s celkovou všímavost’ou, konaním s uvedomením a nehodnotením vlastných zážitkov. Explorujúce správanie koreluje s pozorovaním vlastných zážitkov, popisovaním vlastných zážitkov, konaním s uvedomením a nereagovaním na vlastné zážitky. Výsledky naznačujú, že pri skúmaní súvislosti medzi všímavostou a rizikovým správaním môže záležat' na konkrétnom aspekte všímavosti.
\end{abstract}

Kl'účové slová: rizikové správanie, všímavost', adolescencia

\section{1 ÚVOD}

Adolescencia je vel'mi citlivým obdobím pre rozvoj rizikového správania (Macek, 2003). Ide o špecifické vývinové obdobie pre porozumenie patológii l'udského správania a pre identifikáciu príčin neúspešného vývinu človeka. Bez stretu so závažnými psychickými, sociálnymi či zdravotnými problémami týmto obdobím prejde väčšina jednotlivcov. V tomto období však dochádza $\mathrm{k}$ prudkému nárastu rizikových faktorov, ktoré tak následne ovplyvňujú fyzické či mentálne zdravie jednotlivca (Compas, Reeslund, 2009). Do určitej miery je rizikové správanie pokladané za normatívnu súčast' vývinu (Kováčová, 2008). Toto tvrdenie sa opiera o skutočnost', že až 50 percent adolescentov sa $\mathrm{v}$ priebehu dospievania zapojí do minimálne jednej z foriem rizikového správania (Dryfoos, 1990; Smart et al., 2004). Navzdory tomu sa v posledných rokoch zvýšilo percento dospievajúcich, ktorí sa vydali cestou rizikového spôsobu života, ktorého následky môžu byt’ ohrozujúce až poškodzujúce (Kabíček, Csémy, Hamanová,, 2014). Práve preto v predkladanom výskume venujeme pozornost' rizikovému správaniu adolescentov, a to v súvislosti so všímavost'ou, ktorej prínosy sú v súčasnosti predmetom intenzívneho psychologického skúmania - napr. súvislost' všímavosti s pozitívnou afektivitou a životnou spokojnost'ou (Lučanská, 2019), efektívnost' terapeutických prístupov založených na všímavosti (Hoffmann, Sawyer, Witt, Oh, 2010) a pod. Ciel'om našej štúdie je skúmat', či rizikové správanie adolescentov súvisí s ich všímavost'ou, a to aj na úrovni jednotlivých aspektov všímavosti.

\subsection{Rizikové správanie}

K fenoménu rizikového správania sa vyžaduje prístup medziodborového pohl'adu vd'aka rozsiahlosti pojmu. Nielsen Sobotková et al. (2014) to vysvetl'ujú tým, že sa tieto pojmy často vyskytujú v rámci konceptov a teórií, ktoré sa usilujú o vysvetlenie ich podstaty biologickými, psychologickými alebo sociálnymi príčinami či ich kombináciou. Na širokú a nehomogénnu 
skupinu pojmov charakterizujúcich rizikové správanie vo svojej štúdii upozorňuje Šafářová (2002). Hovorí o tomto správaní ako o správaní nevykazujúcom nebezpečenstvo trestného činu, no o porušujúcom normy danej spoločnosti. Uvádza pojmy ako rizikové správanie, problémové správanie, delikvencia, preddelikventné správanie a poruchy správania. Macek (2003) definuje rizikové správanie ako pojem komplexný, ktorým sa zaoberajú ako spoločenskovedné odbory, tak aj odbory medicínske. Nielsen Sobotková et al. (2014) sa zaoberali správaním, ktoré priamo alebo nepriamo vyúst’uje v psychosociálne, či zdravotné poškodenie jednotlivca, iných osôb, prostredia alebo majetku. Radia k rizikovému správaniu záškoláctvo, agresivitu, agresívne správanie, šikanu, či kyberšikanu, správanie, ktoré je násilné, kriminalitu, vandalizmus, správanie závislé, rizikové správanie na internete, rizikové sexuálne správanie, rizikové správanie $\mathrm{v}$ doprave, hazard, extrémne športy, užívanie anabolík a steroidov, stravovacie návyky, ktoré sú nezdravé, prejavy extrémizmu, xenofóbie, rasizmu, intolerancie a antisemitizmu.

$\mathrm{Na}$ vzniku rizikového správania majú podiel rôzne faktory. Tie rozdel’ujeme na rizikové a protektívne podl'a toho, ako vplývajú na rozvoj rizikového správania (Cocherová, 2015). Jessor et al. (2003) charakterizujú rizikové a protektívne faktory nasledovne. Tým, že rizikové faktory ponúkajú rizikové modely správania, možnosti a taktiež vyššiu osobnú náchylnost' k zapojeniu sa do tohto typu správania, zvyšujú tým pravdepodobnost' vzniku rizikového správania. Protektívne faktory zahŕňajú poskytovanie modelov prosociálneho a pozitívneho správania ako sociálnej a osobnej kontroly. Tie sú namierené proti vzniku rizikového správania a jeho rozvoja.

\subsubsection{Rizikové správanie $v$ adolescencii}

Obdobie dospievania (adolescencie) je vývinovým obdobím, ktoré je vymedzené vekom od 15 do 20-22 rokov (Langmeier, Krejčířová, 1998) a zároveň je vel'mi citlivým pre rozvoj rizikového správania (Macek, 2003). Je dôležité spomenút', že nie všetci adolescenti sú zapojení do rizikového správania. Navzdory tomuto tvrdeniu je obdobie adolescencie v porovnaní s inými vývinovými obdobiami charakteristické vyšším sklonom k rizikovému správaniu. Rizikové správanie sa stalo jedným z atribútov tohto obdobia. Vel'ká čast' adolescentov má totiž s rizikovým správaním skúsenosti (Širůček, Širůčková, Macek, 2007). Jednotlivci, disponujúci rôznymi nedostatkami a prednost'ami, si v období adolescencie určujú mieru nebezpečenstva, ktorú ochotne podstupujú. Z tejto skupiny jednotlivcov, sú však aj takí, ktorí sa tomuto riziku rozhodnú nevystavit' (Orvin, 2001).

Svetová zdravotnícka organizácia (WHO) popísala syndróm rizikové správania v dospievaní (SRCH-D) kvôli faktu, že adolescenti predstavujú samostatnú rizikovú skupinu. Syndróm rizikového správania $\mathrm{v}$ dospievaní zahŕňa tri oblasti, ktoré sa vzájomne kombinujú, spoločne ul'ahčujú svoj vznik a majú spoločné príčiny: 1. abúzus návykových látok, 2. negatívne javy v psychosociálnej oblasti (zahŕňa maladaptáciu, poruchy správania, agresivitu, delikvenciu, kriminalitu, sebapoškodzovanie, suicidalitu a sociálne fóbie a 3. rizikové správanie v reprodukčnej oblasti (Hamanová, Kabíček, 2001; Kabíček, Csémy, Hamanová, 2014). Nielsen Sobotková et al. (2014) taktiež vymedzujú niekol'ko oblastí/foriem rizikového správania adolescentov, a to delikventné správanie, užívanie drog, sexuálne rizikové správanie, poruchy príjmu potravy, sabapoškodzovanie a samovražedné konanie.

\subsubsection{Explorujúce správanie ako typ rizikového správania}

Vyššie spomenuté definície a formy rizikového správania zdôrazňujú hlavne negatívne dôsledky rizika a vylučujú také rizikové správanie, ktoré pravdepodobne povedie k pozitívnym dôsledkom. Takýmto správaním môže byt' napr. postavenie sa rovesníkom alebo skúšanie nových športov. Skúšanie nových športov, protirečenie rovesníkom v názoroch alebo požiadavkách nie je typicky označované za rizikové správanie. Navzdory tomu so sebou prináša riziká zranenia, sklamania a sociálneho odmietnutia (Skaar, 2009). Rozšírená definícia rizika zahŕňa váhu negatívnych a pozitívnych dôsledkov spojených s konkrétnym správaním (Byrnes, Miller, Schafer, 1999). Ak má 
jednotlivec pocit, že sú pozitívne dôsledky prevyšované nad negatívnymi, je pravdepodobné, že sa pustí do riskovania. Z pohl'adu adolescenta môže užívanie drog viest' k negatívnym dôsledkom ako uväznenie alebo zdravotné problémy, na druhej strane k pozitívnemu dôsledku vo forme skvelého pocitu. Účast’ na extrémnych športových aktivitách je taktiež riskom, ktorý sú mnohí adol escenti ochotní prijat'. V tomto prípade môže dôjst' k pozitívnym dôsledkom vo forme rozvoja nových zručností a pocitu úspechu (Skaar, 2009).

Irwin and Vaughan (1988) označili správanie, ktoré vedie k pozitívnym dôsledkom ako „explorujúce správanie“. Toto označenie však ešte nie je v odbornej literatúre bežne zaužívané (Skaar, 2009). Nie je jednoduché označovat' určitý typ správania ako rizikový alebo nerizikový, ked’že správanie označené za negatívne môže viest' ku konštruktívnym dôsledkom (Schulenberg, 2006) a správanie bežne označované ako pozitívne alebo nie rizikové môže byt' pre jednotlivca rizikovým (Skaar, 2009). Skaar (2009) taktiež opisuje takzvané explorujúce či exploratívne správanie ako typ rizikového správania s pozitívnymi následkami. Radí sem účast' na extrémnych športových aktivitách, schôdzky s opačným pohlavím či obraňovanie priatel'ov pri konflikte. Rizikové správanie podl'a autorky N. R. Skaar (2009) môže viest' aj k pozitívnym aj negatívnym dôsledkom, a preto ho rozlišuje na dva typy, a to explorujúce správanie $\mathrm{s}$ väčšou pravdepodobnost'ou pozitívnych dôsledkov v oblasti zdravia a vzdelávania a rizikové správanie spojené so zdravím s vyššou mierou negatívnych zdravotných a vzdelávacích dôsledkov (vid' tab.1). V našej štúdii vychádzame práve z uvedeného členenia rizikového správania podl'a Skaar (2009). V d'alšom texte budeme používat' pre rizikové správanie spojené so zdravím, ktoré prináša vyššiu pravdepodobnost' negatívnych dôsledkov, pojem rizikové správanie. Ako druhý typ rozlišujeme $\mathrm{v}$ súlade $\mathrm{s}$ autorkou explorujúce správanie s vyššou pravdepodobnost'ou pozitívnych dôsledkov.

Tab. 1 Dôsledky rizikového a explorujúceho správania

Rizikové správanie

Explorujúce správanie

\begin{tabular}{ccccc}
\hline $\begin{array}{c}\text { Užívanie } \\
\text { látok }\end{array}$ Záškoláctvo & Krádeže & $\begin{array}{c}\text { Vytváranie } \\
\text { kamarátstiev }\end{array}$ & $\begin{array}{c}\text { Skúšanie } \\
\text { nových } \\
\text { športov }\end{array}$ & $\begin{array}{c}\text { Zastanie } \\
\text { rovesníka }\end{array}$ \\
\hline
\end{tabular}

\begin{tabular}{|c|c|c|c|c|c|c|}
\hline \multicolumn{7}{|l|}{ Pozitívne dôsledky } \\
\hline Vnútorné stimuly & $X$ & & $X$ & $X$ & $X$ & $X$ \\
\hline Spoločenské prijatie & $X$ & $X$ & $X$ & $X$ & & $X$ \\
\hline Menšia úzkost' & $X$ & & & $X$ & $X$ & \\
\hline $\begin{array}{l}\text { Nižšia miera } \\
\text { vyčleňovania }\end{array}$ & & & & & $X$ & \\
\hline $\begin{array}{c}\text { Menej delikventného } \\
\text { správania }\end{array}$ & & & & & & $X$ \\
\hline $\begin{array}{c}\text { Väčší akademický } \\
\text { úspech }\end{array}$ & & & & & $X$ & \\
\hline \multicolumn{7}{|l|}{ Negatívne dôsledky } \\
\hline Smrt' & $X$ & & & & & \\
\hline Zranenie & $X$ & & & & $X$ & \\
\hline $\begin{array}{l}\text { Slabá školská } \\
\text { angažovanost' }\end{array}$ & $X$ & & & & & \\
\hline Sociálne odmietnutie & $X$ & $X$ & $X$ & $X$ & $X$ & $X$ \\
\hline
\end{tabular}


Pomáhajúce profesie, roč. 3, č. 2, 2020, 33-44

\begin{tabular}{cccc}
$\begin{array}{c}\text { Slabší akademický } \\
\text { úspech }\end{array}$ & $X$ & $X$ & \\
Trest & $X$ & $X$ & $X$ \\
$\begin{array}{c}\text { Predčasné ukončenie } \\
\text { školskej dochádzky }\end{array}$ & $X$ & $X$ & \\
\hline
\end{tabular}

Zdroj: Skaar, 2009, str. 19

\subsection{Všímavost'}

Všímavost' (alebo mindfulness v zahraničnej literatúre, možno sa stretnút' aj s prekladom bdelá pozornost') je pojem, ktorý pochádza z budhizmu, no našiel si svoje miesto aj v súčasnej psychológii (Jurkovič, 20015). Aj ked' sa koncept všímavosti zrodil v budhistickej psychológii, jeho tradícia je omnoho globálnejšia. Príbuzné konštrukty sa objavili v gréckej filozofii, či v koncepciách západoeurópskych, ako aj amerických myslitel'ov, ktoré sa stali súčast'ou fenomenologických, existenciálnych, naturalistických, transcendentálnych a humanistických prístupov (Brown, Ryan, Creswell, 2007).V súčasnosti neexistuje jednotná definícia všímavosti. Niektorí autori ju chápu ako situačnú charakteristiku alebo vlastnost’ vedomia, iní ako dispozíciu, či už v zmysle osobnostnej črty alebo schopnosti, d'alší ako špecifický stav bytia, resp. spôsob spracúvania obsahov prežívania (Látalová, Pilárik, 2014). Kabat-Zinn (2003) definuje všímavost' ako uvedomovanie si, ktoré vyvstáva $\mathrm{z}$ úmyselného sústredenia pozornosti $\mathrm{v}$ prítomnom okamihu a bez posudzovania odhal'ujúcej sa skúsenosti prebiehajúcej okamih za okamihom. Podl'a Bendu (2007) je všímavost' prirodzená schopnost' byt' duchom teraz a tu - nezaujato registrovat' prežívané psychické a telesné fenomény v prítomnosti. Definícia Browna a Ryana (2003, s. 822) popisuje všímavost' ako "stav receptívnej pozornosti a uvedomovania si práve prítomných udalostí a zážitkov". Všímavost' nám má pomôct' preskúmat' to kým sme, aký máme svetonázor, zvážit' naše miesto v tomto svete. Môže nás naučit' ocenit' všetky okamihy života $\mathrm{v}$ ich komplexnosti. Hlavná je však možnost' stretu $\mathrm{s}$ realitou (Kabat-Zinn, 2009).

Všímavost' má celý rad aspektov, ktoré sú prepojené a vzájomne sa ovplyvňujú. Skupina autorov Baer, Smith, Hopkins, Krietemeyer a Toney (2006) definovala všímavost' prostredníctvom piatich aspektov (pozorovanie vlastných zážitkov, popisovanie vlastných zážitkov, konanie na základe uvedomovania, nehodnotenie vlastných zážitkov a nereagovanie na vlastné zážitky), ktoré si v nasledujúcom texte stručne predstavíme. Pozorovanie vlastných zážitkov vyjadruje registrovanie a venovanie pozornosti vnútorným aj vonkajším vnemom, ktorými môžu byt' pocity, kognitívne schopnosti, emócie, zvuky či vône. Popisovanie vlastných zážitkov sa viaže k schopnosti previest' vlastné vnútorné zážitky do slovnej podoby. Konanie na základe uvedomovania spočíva v schopnosti vykonávat' činnost' s plným vedomím, bez úteku myšlienok iným smerom. Zahŕňa vyvarovanie sa zautomatizovanému správaniu a mysleniu. Nehodnotenie vlastných zážitkov zahŕňa nezaujatý postoj k vlastným myšlienkam a emóciám. Nereagovanie na vlastné zážitky sa vzt’ahuje k vnútorným skúsenostiam a znamená schopnost' jednotlivca nechat' myšlienky a pocity prirodzene plynút', namiesto toho, aby sa nimi nechával príliš uniest' (Baer et al., 2006; 2008). V našej štúdii vychádzame práve z uvedenej koncepcie (Baer et al, 2006) zameranej na pät' aspektov všímavosti.

\subsection{Všímavost' vo vzt'ahu $\mathrm{k}$ rizikovému správaniu adolescentov}

Všímavost' a jej prínosy sú v súčasnosti predmetom intenzívneho psychologického skúmania. Možno sa zamerat' na jej pozitívne účinky pri terapii chronickej bolesti, porúch nálady, pri redukcii stresu či prevencii somatických ochorení (napr. Hayes, 2004; Hoffmann, Sawyer, Witt, Oh, 2010; 
Davidson et al., 2003) a jej súvislost' s pozitívnou afektivitou a životnou spokojnost'ou (napr. Lučanská, 2019). Vzhl'adom k uvedeným pozitívnym účinkom všímavosti a narastajúcemu percentu adolescentov inklinujúcich k rizikovému správaniu, ktorého následky môžu byt' ohrozujúce až poškodzujúce (Kabíček, Csémy, Hamanová, 2014), považujeme za zmysluplné preskúmat' vzt'ah všímavosti (a jej aspektov) krizikovému a explorujúcemu správaniu adolescentov. Opierame sa pri tom o výskum Blacka (2011), podl'a ktorého všímavost' môže chránit’ pred rozhodovacími procesmi, ktoré vystavujú mládež riziku fajčenia a podporuje tak teóriu, že všímavost' môže mat’ súvis s rizikovým správaním adolescentov akým je napr. fajčenie. Na základe výskumu Hofmanna et al.. (2010), ktorí popisujú vplyv všímavosti pri liečbe úzkostí a afektívnych porúch v rámci klinickej populácie sa domnievame, že všímavost' by mohla súvisiet’ s niektorými typmi rizikového správania, akými sú napr. poruchy príjmu potravy či sebapoškodzovanie, nakol'ko sú tieto typy správania motivované aj spomínanou úzkost'ou. Všímavejší jednotlivci pocit'ujúci menej úzkostí by tak mohli mat' zároveň nižšiu tendenciu k rizikovému správaniu. Autori Mirčevská (2008) a Žitník (2010) vo svojich výskumoch preukázali pozitívny účinok pravidelnej meditácie na úroveň subjektívnej pohody a pozitívnu koreláciu medzi úrovňou všímavosti a životnej spokojnosti. Gecková, Pudelský, Tuinstra a Van Dijk (2000) zas uvádzajú, že miera subjektívnej pohody súvisí typmi rizikového správania, akým je napr. užívanie látok. Na základe zistenej súvislosti medzi všímavost'ou a životnou spokojnost'ou resp. subjektívnou pohodu, ktorá je asociovaná s niektorými typmi rizikového správania, predpokladáme súvis všímavosti so samotným rizikovým správaním. Na základe kognitívnobehaviorálneho prístupu, ktorý sa zameral na aplikáciu konceptu všímavosti do nových prístupov ako Mindfulness Based Stress Reduction, zameraného na redukciu stresu prostredníctvom všímavosti, si myslíme, že všímavost' by mohla súvisiet' s nižšou mierou takého rizikového správania, ktoré je motivované práve úzkost'ou, stresom a napätím. Kocourková a Koutek (2005) uvádzajú, že napr. sebapoškodzovanie býva motivované hnevom na vlastnú osobu či uvol'nením napätia.

Vychádzajúc z vyššie popísaných zistení predpokladáme, že všímavost' ako celok, a tiež jej jednotlivé aspekty súvisia s rizikovým a explorujúcim správaním. V prípade explorujúceho správania predpokladáme pozitívny vzt'ah so všímavost'ou a jej aspektmi, nakol'ko ide o správanie s vyššou pravdepodobnost'ou pozitívnych dôsledkov. V prípade rizikového správania predpokladáme negatívny vzt'ah $\boldsymbol{k}$ všímavosti a jej aspektom, a teda si na podklade zmienených výskumov myslíme, že vyššia všímavost' môže súvisiet' s nižšou mierou rizikového správania, pre ktoré sú typické negatívne dôsledky.

\section{METÓDY}

\subsection{Výskumná vzorka}

Výskumnú vzorku tvorilo 166 študentov prvého, druhého, tretieho a štvrtého ročníka dvoch stredných škôl v Košiciach (gymnázium a stredná odborná škola). Z hl'adiska pohlavia bol súbor zložený z 51 chlapcov a 115 dievčat. Priemerný vek participantov bol $\mathrm{M}_{\mathrm{vek}}=17,2\left(\mathrm{SD}_{\mathrm{vek}}=1,49\right)$.

\subsection{Meracie nástroje}

Na meranie rizikového správanie sme použili Škálu explorujúceho a rizikového správania adolescentov (Adolescent Explorary and Risk Behaviour Rating Scale - AERRS; Skaar, 2009). Dotazník má dve časti, pričom prvá je zameraná na meranie rizikového správania spojeného so zdravím a na meranie explorujúceho správania. Druhá čast' je zameraná na zist'ovanie percepcie rizika. K výskumným účelom našej štúdie sme využili prvú čast' obsahujúcu výroky zodpovedajúce rizikovému a explorujúcemu správaniu. Participanti vyjadrujú frekvenciu s akou sa zapájajú do týchto aktivít na nasledujúcej škále: 1 - nikdy, 2 - zriedka, 3 - niekedy, 4 - často. 
Všímavost' bola meraná prostredníctvom Dotazníka piatich aspektov všímavosti (Five Facet Mindfulness questionnaire - FFMQ), ktorého autormi sú Baer et al. (2006). Dotazník bol vytvorený na základe faktorovej analýzy piatich už existujúcich nástrojov k meraniu všímavosti. Dotazník pozostáva $\mathrm{z}$ piatich subškál zodpovedajúcich vyššie charakterizovaným piatim aspektom všímavosti (pozorovanie vlastných zážitkov, popisovanie vlastných zážitkov, konanie s uvedomením, nehodnotenie vlastných zážitkov, nereagovanie na vlastné zážitky). Položky vo forme výrokov, ktoré predstavujú alternatívy odpovedí na otázku „Ako často mávate nasledovné zážitky?" sú hodnotené na 5-bodovej škále (1 - nikdy alebo vel'mi zriedka, 5 - vel'mi často alebo vždy) (Látalová, Pilárik, 2014). Podl'a Látalovej a Pilárika (2014), ktorí overovali psychometrické vlastnosti FFMQ v slovenských podmienkach, ide o reliabilný a validný nástroj.

\section{3 Štatistické spracovanie dát}

Štatistické spracovanie dát sme realizovali v programe IBM SPSS Statistics 24.0. Vzt’ahy všímavosti a jej aspektov k rizikovému a explorujúcemu správaniu sme zist'ovali prostredníctvom Pearsonovej súčinovej korelácie vzhl’adom k normálnej distribúcii dát.

\section{VÝSLEDKY}

Korelovali sme všímavost’ a jej jednotlivé aspekty s rizikovým a explorujúcim správaním. Výsledky uvádzame v tab.2.

Tab. 2 Vzt'ah všímavosti a jej aspektov k rizikovému a explorujúcemu správaniu

\begin{tabular}{ccccc} 
& \multicolumn{2}{c}{ Rizikové správanie } & \multicolumn{2}{c}{ Explorujúce správanie } \\
\cline { 2 - 5 } & $\mathrm{r}$ & $\mathrm{p}$ & $\mathrm{r}$ & $\mathrm{p}$ \\
\hline Všímavost' & 0,197 & 0,011 & 0,144 & 0,063 \\
Pozorovanie vlastných zážitkov & $-0,051$ & 0,510 & 0,296 & $<0,001$ \\
Popisovanie vlastných zážitkov & 0,085 & 0,278 & 0,343 & 0,000 \\
Konanie s uvedomením & 0,178 & 0,022 & $-0,226$ & 0,003 \\
Nehodnotenie vlastných zážitkov & 0,236 & 0,002 & $-0,138$ & 0,076 \\
Nereagovanie na vlastné zážitky & 0,048 & 0,542 & 0,290 & $<0,001$
\end{tabular}

Legenda: $r$ - Pearsonov koeficient súčinovej korelácie; $p$ - štatistická signifikancia

Zistili sme štatisticky významný pozitívny vzt’ah medzi celkovou všímavost'ou a rizikovým správaním, pričom z hl'adiska sily ide o slabý vzt’ah. Explorujúce správanie na základe našich výsledkov nevykazuje významný vzt'ah k celkovej všímavosti. Čo sa týka jednotlivých aspektov všímavosti, pozorovanie vlastných zážitkov slabo pozitívne koreluje s explorujúcim správaním a nekoreluje s rizikovým správaním. Podobne aj popisovanie vlastných zážitkov pozitívne koreluje s explorujúcim správaním (stredne silno) a nekoreluje s rizikovým správaním. Konanie s uvedomením je v slabom pozitívnom vzt’ahu s rizikovým správaním a v slabom negatívnom 
vzt’ahu s explorujúcim správaním. Nehodnotenie vlastných zážitkov vykazuje slabý pozitívny vzt’ah s rizikovým správaním, ale nevykazuje významný vzt’ah s explorujúcim správaním. Pri nereagovaní na vlastné zážitky zist’ujeme jeho vzt'ah s explorujúcim správaním, pričom ide o slabý pozitívny vzt’ah. Nereagovanie na vlastné zážitky na základe našich výsledkov nevykazuje významný vzt’ah k rizikovému správaniu.

\section{DISKUSIA}

Ciel'om predkladanej štúdie bolo skúmat' vzt'ah medzi všímavost'ou a rizikovým správaním adolescentov, a to $\mathrm{z}$ dôvodu narastajúceho percenta adolescentov inklinujúcich k rizikovému správaniu (Kabíček, Csémy, Hamanová, 2014) a tiež vzhl’adom k výsledkom štúdií poukazujúcich na pozitívne účinky všímavosti v rôznych oblastiach (napr. napr. Hayes, 2004; Hoffmann, Sawyer, Witt, Oh, 2010; Davidson, 2003 a iné). Zamerali sme sa na zist’ovanie vzt'ahu všímavosti ako celku aj jej jednotlivých aspektov nielen k rizikovému, ale aj explorujúcemu správaniu. V súlade s autorkou Skaar (2009) sme rozlišovali rizikové správanie spojené s vyššou mierou negatívnych zdravotných a vzdelávacích dôsledkov a explorujúce správanie vedúce $\mathrm{s}$ väčšou pravdepodobnost'ou k pozitívnym dôsledkom v oblasti zdravia a vzdelávania. Výsledky o vzt'ahu všímavosti (a jej aspektov) k rizikovému a explorujúcemu správaniu postupne diskutujeme.

Pri všímavosti ako celku sme zistili pozitívny vzt’ah s rizikovým správaním, čo je v rozpore s našim predpokladom. Avšak ide len o slabý vzt'ah $(\mathrm{r}=0,197)$, ktorý mohol dosiahnut' úroveň štatistickej významnosti vzhl'adom na vel'kost' výskumnej vzorky, ked'že podl'a Cohena (1988) vel'kost' výskumnej vzorky ovplyvňuje štatistickú silu. Taktiež je možné, že zistenie vzt'ahu medzi všímavost'ou a rizikovým správaním sa môže odvíjat' od konkrétnej formy rizikového správania, akými sú napr. poruchy príjmu potravy, na čo poukazuje Grados (2013). Jeho výskum hovorí o pozitívnom vzt'ahu medzi všímavost'ou a poruchami príjmu potravy - dievčatá s vyššou úrovňou všímavosti majú väčšie sklony k poruchám príjmu potravy. V prípade celkovej všímavosti a explorujúceho správania sme významný vzt’ah nezistili, čo sa nezhoduje s našim predpokladom. Ak sa však pozrieme na jednotlivé aspekty všímavosti, nachádzame okrem aspektu nehodnotenia zážitkov vzt’ahy kexplorujúcemu správaniu (pozitívne, aj jeden negatívny). Uvedené môže naznačovat', že vo vzt'ahu k explorujúcemu správaniu záleží na konkrétnom aspekte všímavosti.

Prvý aspekt všímavosti, pozorovanie vlastných zážitkov, ktoré je charakterizované ako venovanie pozornosti vnútorným aj vonkajším vnemom, pocitom, emóciám, zvukom, kognitívnym schopnostiam, vôňam atd'. (Baer et al., 2008) nevykazuje významný vzt'ah s rizikovým správaním. Výsledok nie je v súlade s našim predpokladom, ani s výskumami, z ktorých sme vychádzali (napr. Black, 2011; Hofmann, Sawyer, Witt, Oh, 2010). Na druhej strane, podporu nášho zistenia nachádzame vo výskume Kubotu (2013), kde sa nepreukázal vzt'ah medzi všímavost’ou a rizikovým správaním (konkrétne sexuálne rizikovým správaním). Čo sa týka explorujúceho správania, náš predpoklad o jeho pozitívnom vzt’ahu s pozorovaním vlastných zážitkov sa potvrdil, i ked' si uvedomujeme, že ide o slabý vzt'ah.

Pri druhom aspekte všímavosti, popisovaní vlastných zážitkov, podobne ako v predošlom prípade nenachádzame vzt'ah s rizikovým správaním, čo sme nepredpokladali. Výsledok naznačuje, že popisovanie vlastných zážitkov, teda schopnost' previest' vlastné vnútorné zážitky do slovnej podoby (Baer et al., 2008) nesúvisí s rizikovým správaním. Na druhej strane táto schopnost' na základe našich výsledkov súvisí s explorujúcim správaním, čo je konzistentné s našim predpokladom. Znamená to, že jednotlivci, ktorí majú vyššiu schopnost' svoje vnútorné zážitky nie len registrovat', ale ich aj slovne popísat' sa viac zapájajú do explorujúceho správania, teda do správania, ktoré im s vyššou pravdepodobnost'ou prináša pozitívne dôsledky. Podl'a Skaar (2009) môže íst' napr. o zapájanie sa do nových športových aktivít, čo môže mat' za následok redukciu 
úzkosti, ktorú ako jeden z vnútorných prežitkov dokážu všímavejší jednotlivci lepšie zachytit' a popísat'.

V prípade aspektu konania s uvedomením sme zistili pozitívny vzt'ah s rizikovým správaním, čo nie je v súlade s našim predpokladom. Je potrebné spomenút', že ide o najslabší zistený vzt'ah $(\mathrm{r}=0,178)$, ktorý mohol dosiahnut' hladinu štatistickej významnosti len vzhl'adom k vel'kosti výskumnej vzorky (n=166). Zároveň však ide o vzt’ah opačného smeru, aký sme predpokladali. Vysvetlenie tohto vzt’ahu ponúka výskum Harrisa (2012), podl’a ktorého adolescenti využívajú všímavost', aby regulovali užívanie látok, $\mathrm{v}$ tomto prípade alkoholu, namiesto toho, aby sa takémuto správaniu vyhli. Vychádzajúc z uvedeného sa domnievame, že všímavejší jednotlivci v zmysle väčšej schopnosti vykonávat' činnost' s plným vedomím, sa môžu púšt'at' do rizikového správania, ktoré si uvedomujú a všímavost' využívajú na jeho reguláciu. Na druhej strane konanie suvedomením vykazovalo slabý negatívny vzt’ah sexplorujúcim správaním, čo sme nepredpokladali. To znamená, že vyššia miera konania s plným vedomím súvisí s nižším výskytom explorujúceho správania, akým je napr. zastanie sa rovesníka, ktorý je šikanovaný. Skaar (2009) popisuje explorujúce správanie ako typ rizikového správania, ktoré so sebou prináša hlavne pozitívne dôsledky. Navzdory tomu sa tu môžu vyskytnút' aj negatívne dôsledky. Ked' hovoríme napríklad o zastaní sa vrstovníka, ktorý je šikanovaný, negatívnym dôsledkom tohto explorujúceho správania môže byt' sociálne odmietnutie. Uvažujeme nad tým, že jednotlivci s vyššou mierou konania s uvedomením si naplno uvedomujú pozitívne ale aj negatívne dôsledky explorujúceho správania, čo môže viest' k tomu, že sa toto správanie u nich vyskytuje v menšej miere.

Pri aspekte nehodnotenia vlastných zážitkov, ktoré predstavuje zaujatie nehodnotiaceho postoja $\mathrm{k}$ svojim myšlienkam či pocitom, sme podobne ako v predošlom prípade zistili slabý pozitívny vzt’ah s rizikovým správaním, čo sme neočakávali. Aj tu sa odvoláme na výskum Harrisa (2012), kde sa zistilo, že adolescenti využívajú všímavost' aby regulovali užívanie látok (konkrétne alkoholu), namiesto toho, aby sa rizikovému správaniu vyhli. Je teda možné, že adolescenti, ktorí majú tendenciu vo väčšej miere zaujat' voči svojim myšlienkam a pocitom nehodnotiaci postoj sa zapájajú do rizikového správania, ktoré však prostredníctvom všímavosti regulujú. V prípade explorujúceho správania sme vzt’ah s nehodnotením vlastných zážitkov nezistili.

Pri poslednom aspekte všímavosti, nereagovaní na vlastné zážitky, sme narozdiel od rizikového správania zistili vzt’ah s explorujúcim správaním. Pozitívny vzt’ah medzi nereagovaním na vlastné zážitky a explorujúcim správaním je v súlade s naším predpokladom. Výsledky naznačujú, že u jednotlivcov s vyššou mierou nereagovania na vlastné zážitky, teda u jednotlivcov s vyššou schopnost'ou nechat' myšlienky a pocity prirodzene plynút', namiesto toho, aby sa nimi nechávali príliš uniest' (Baer et al., 2008), sa vo vyššej miere objavuje explorujúce správanie, ktoré je podl'a Skaar (2009) charakterizované väčšou pravdepodobnost'ou pozitívnych dôsledkov pre jednotlivca. 


\section{ZÁVER}

Štúdia skúmala súvislost' všímavosti a jej aspektov k rizikovému a explorujúcemu správaniu. Jednotlivé zistenia boli v príspevku podrobne diskutované. Podrobnejšie preskúmanie vzt'ahu medzi všímavost’ou a rizikovým, ako aj explorujúcim správaním na úrovni jednotlivých aspektov všímavosti sa javí ako zmysluplné, nakol'ko zmienené zistenia poukazujú na to, že niektoré aspekty všímavosti súvisia a iné nesúvisia s rizikovým a tiež explorujúcim správaním. Dokonca v prípade explorujúceho správania má jeden vzt’ah (vzt’ah explorujúceho správania s aspektom konania s uvedomením) iný smer ako vzt'ahy s ostatnými aspektmi všímavosti. Za prínosné považujeme tiež rozlíšenie a skúmanie rizikového a explorujúceho správania zvlášt'. Na základe výsledkov, ktoré v niektorých prípadoch neboli konzistentné s našimi predpokladmi, a tiež vzhl'adom na zistené prevažne slabé vzt’ahy si však myslíme, že pri vzt'ahu medzi všímavost'ou a rizikovým správaním záleží nielen na danom aspekte všímavosti, ale aj na konkrétnom type/oblasti rizikového správania (napr. sexuálne rizikové správanie, užívanie látok a pod.), čo by bolo vhodné dôkladnejšie preskúmat' v nasledujúcom výskume. Ten odporúčame realizovat' na vzorke, ktorá by bola v porovnaní s predkladanou štúdiou vyrovnanejšia vzhl'adom na pomer mužov a žien.

\section{LITERATÚRA}

Baer, R. A., Smith, G. T., Hopkins, J., Krietemeyer, J., \& Toney, L. (2006). Five Facet Mindfulness Questionnaire. University of Kentucky, Lexington, Kentucky.

Baer, R. A., Smith, G. T., Lykins, E., Button, D., Krietemeyer, J., Sauer, S., Walsh, E., Duggan, D., \& Williams, J. M. G. (2008). Construct validity of the five facet mindfulness questionnaire in meditating and nonmeditating samples. Assessment, 15(3), 329-342

Benda, J. (2007). Všímavost v psychologickém výzkumu a v klinické praxi. Československá psychologie, 51(2), $129-140$.

Black, D. S. (2011). The effects of mindfulness on adolescent cigarette smoking:measurement, mechanisms, and theory (dizertačná práca). California: University of Southern California.

Brown, K. W., \& Ryan, R. M. (2003). The benefits of being present: Mindfulness and its role in psychological well-being. Journal of Personality and Social Psychology, 84(4), 822-848.

Brown, K. W., Ryan, R. M., \& Creswell, J. D. (2007). Mindfulness: Theoretical foundations and evidence for its salutary effects. Psychological Inquiry, 18(4), 211-237.

Byrnes, J. P., Miller, D. C., \& Schafer, W. D. (1999). Gender difference in risk taking: A meta-analysis. Psychological Bulletin, 125, 367-383.

Cocherová, M. (2015). Online rizikové správanie žiakov stredných škôl (diplomová práca). Nitra: UKF.

Cohen, J. (1988). Statistical power analysis for the behavioral sciences. New York: Lawrence Erlbaum Associates.

Compas, B. E., \& Reeslund, K. L. (2009). Processes of risk and resilience during adolescence. In R. M. Lerner \& L. Steinberg (Eds.), Handbook of adolescent psychology: Individual bases of adolescent development (561-588). John Wiley \& Sons.

Davidson, R. J., Kabat-Zinn, J., Schumacher, J., Rosenkranz, M., Muller, D., Santorelli, S. F., ... \& Sheridan, J. F. (2003). Alterations in brain and immune function produced by mindfulness meditation. Psychosomatic medicine, 65(4), 564-570. 
Dryfoos, J., G. (1990). Adolescents at Risk: Prevalence and Prevention. New York: Oxford University Press.

Gecková, A., Pudelský, M., Tuinstra, J., \& Van Dijk, J. P. (2000). Vplyv fajčenia, konzumovania alkoholu, užívania drog a nedostatku fyzickej aktivity na zdravie adolescentov. Československá psychologie, 44 (2), 132 - 147.

Grados, E. K. (2013). Mindfulness and its Relationship To Body Satisfaction and Risk of an Eating Disorder in College Women (dizertačná práca). Chicago: Chicago School of Professional Psychology.

Hamanová, J., \& Kabíček, P. (2001). Syndrom rizikového chování v dospívání. Zdravotnické noviny: Lékařské listy, 50(4), 38-40.

Harris, J. (2012). Mindfulness Training: Impact of Coping and Self-Efficacy in Adolescent Substance Use (dizertačná práca). Seattle: Seattle Pacific University.

Hayes, S., C. (2004). Acceptance \& commitment therapy, relational frame theory, and the third wave of behavioral and cognitive therapies. Behavior Therapy, 35(4), 639-665.

Hofmann, S. G., Sawyer, A. T., Witt, A. A., \& Oh, D. (2010). The effect of mindfulness-based therapy on anxiety and depression: A meta-analytic review.Journal of consulting and clinical psychology, 78(2), 169-183.

Irwin, C. E. Jr., \& Vaughan, E. (1988). Psychosocial context of adolescent development: Study group report. Journal of Adolescent Health Care, 9(6), 11-19.

Jessor, R., Turbin, M. S., Costa, F. M., Dong, Q., Zhang, H., \& Wang, C. (2003). Adolescent problem behavior in China and the United States: Across-national study of psychosocial protective factors. Journal of Research on Adolescence, 13, 329-360.

Jurkovič, M. (2015). Miera črtovej všímavosti vo vzt'ahu ku kognitívnym zaujatostiam. In I. Farkaš, M. Tkáč, J. Rybár, J. Kelemen (Eds.), Kognícia a umelý život (1. ed., pp. 67-73). Bratislava: Univerzita Komenského v Bratislave.

Kabat-Zinn, J. (2009). Bárhová mész, ott vagy: Éberségmeditáció a mindennapi életben Budapest: Ursus Libris.

Kabat-Zinn, J. (2003). Mindfulness-based interventions in context: past, present, and future. Clinical psychology: Science and practice, 10(2), 144-156.

Kabíček, P., Csémy, L., \& Hamanová, J. (2014). Rizikové chování v dospívání a jeho vztah ke zdraví. Praha: Triton.

Kocourková, J., \& Koutek, J. (2005). Spektrum autodestruktivity v adolescenci-rizikové chování, sebepoškozování, suicidalita. Psychológia a patopsychológia diet’at'a, 44(4), 374-379.

Kováčová, D. (2008). Sebahodnotenie a rizikové správanie v adolescencii (diplomová práca). Brno: Masarykova Univerzita.

Kubota, E. (2013). Mindfulness and Its Relation To HIV-Risk Behaviors in College Students: Psychological Distress and Attachment as Moderating Factors (dizertačná práca). New York: Yeshiva University.

Langmeier, J., \& Krejčířová, D. (1998). Vývojová psychologie. Praha: Grada. 
Látalová, V., \& Pilárik, L’. (2014). Overenie psychometrických vlastností a faktorovej štruktúry slovenskej verzie dotazníka FFMQ (five-facet mindfulness questionnaire). Psychologie a její kontexty, 5(2), 81-99.

Lučanská, K. (2019). Komponenty konceptu Mindfulness merané seba-posudzovacou škálou FFMQ u univerzitných študentov a ich vzt’ah ku stratégiám regulácie emócií, pozitívnej emotivite, resiliencii, seba-súcitu, reaktivite na stres a životnej spokojnosti: štrukturálny model (diplomová práca). Brno: Masarykova univerzita.

Macek, P. (2003). Adolescence. Praha: Portál.

Mirčevská, P. (2008). Kvalita života u osob praktikujúcich meditaci. Retrieved from https://www.semanticscholar.org/paper/Kvalita-\%C5\%BEivota-u-osob-

praktikuj\%C3\%ADc\%C3\%ADch-meditaci-

Mir\%C4\%8Devsk\%C3\%A1/f309b7ff591b5b8cd72783a5fcfe8c37a627ea01\#references .

Nielsen Sobotková, V., Blatný, M., Hrdlička, M., \& Jelínek, M. (2014). Rizikové a antisociální chovaání $v$ adolescenci. Praha: Grada.

Orvin, G. (2001). Dospívaní - Kniha pro rodiče. Praha: Grada.

Schulenberg, J. E. (2006). Understanding the multiple contexts of adolescent risky behavior and positive development: Advances and future directions. Applied Developmental Science, 10(2), 107113.

Skaar, N. R. (2009). Development of the Adolescent Exploratory and Risk Behavior Rating Scale (dizertačná práca). University of Minnesota.

Smart, D., Vasallo, S., Sanson, A., \& Dussuyer, I. (2004). Patterns of antisocial behavior from early adolescence to late adolescence. Trends \& Issues in crime and criminal justice series, 290, 1-6.

Šafářová, M. (2002). Rizikové chování v adolescenci. In V. Smékal, \& P., Macek, (Eds.), Utváření a vývoj osobnosti: Psychologické, sociální a pedagogické aspekty. (191-209). Brno: Barrister a Principal.

Širůček, J., Širůčková, M., \& Macek, P. (2007). Sociální opora rodičú a vrstevníků a její význam pro rozvoj problémového chování v adolescenci. Československá psychologie, 51(5), 476-488.

Žitník, J. (2010). Všímavost a klinické přístupy založené na jejím rozvíjení (Diplomová práca). Praha: FF, UK.

\section{MINDFULNESS AND RISK BEHAVIOR IN ADOLESCENTS}

Abstract: The aim of the study was to examine the relationship between mindfulness and risk behavior in adolescents. The examination of risk behavior was based on the concept distinguishing health-related risk behavior and exploring behavior, which is defined as behavior for which there is an increased likelihood of positive consequences. The research sample consisted of 166 high school students ( 51 boys and 115 girls) aged from 15 to 20 years $\left(\mathrm{M}_{\mathrm{age}}=17.2\right.$; $\left.\mathrm{SD}_{\mathrm{age}}=1.49\right)$. We used the FiveFacet Mindfulness Questionnaire - FFMQ (Baer et al., 2006) to measure mindfulness and Adolescent Exploratory and Risk Behavior Rating Scale - AERRS (Skaar, 2009) to measure risk behavior. We found out that risk behavior is correlated with global mindfulness, acting with awareness and non-judging of inner experience. Exploratory 
behavior is correlated with observing, describing, acting with awareness and nonreactivity to inner experience. The results suggest that specific aspect of mindfulness may be relevant when examining the relationship between mindfulness and risk behavior.

Keywords: risk behavior, mindfulness, adolescence 